\title{
СВРОПЕЙСЬКА СИСТЕМА ПРАВА У РОЗВИТКУ ДЕРЖАВНО-ЦЕРКОВНИХ ВІДНОСИН В УКРАЇНІ
}

\begin{abstract}
СРМАКОВА Ганна Станіславівна - доктор юридичних наук, професор кафедри теорії держави і права та конституційного права, Міжрегіональна Академія управління персоналом (МАУП)

ПОЛЕВИЙ Володимир Іванович - кандидат юридичних наук, завідувач кафедри теоріï, історії права і держави та конституційного права, старший науковий співробітник, Бердянський Університет менеджменту і бізнесу

DOI 10.32782/EP.2021.4.3
\end{abstract}

В статье рассмотренъ европейские модели церковно-государственнъгх отношений. Определено, ито политика сотрудничества государства и иеркви приобрела новое содержание в последние годъ в странах ЕС из-за влияния негативных факторов от последствий трансформачионнъгх процессов, связаннъгх с интеграчией. Именно поэтому государственно-иерковные отношения требуют именно кооперачии, а не только сосуществования или взаимодействия, основанного на системе определенньх общих условий. Демократические принципъ заложенъи в основе общепринятьх международнъх положений, относящихся к религиозной свободе и сфере правового регулирования отношений государства и религиознъгх объединений в Европе. Европейские нормы, регулирующие права человека и гражданина, постепенно имплементировали новую борму организачии светской и церковной власти. Это позволяет говорить о существовании или объективном воспроизводстве и будущей бормащии новой прогрессивной пан-европейской модели государственно-церковнъхх отношений, которую с учетом начиональньх особенностей целесообразно заимствовать в Украине для дальнейшей демократизаиии общественнъих процессов.

Освещено наличие межконфессиональных конфбликтов в Украине, требуюших разрешения с помощью богословских и Европейских правовых механизмов.

Ключевъе слова: государство, Церковь, государственно-церковная модель, государственно-церковнъие отношения, религия, общество, конфессия.
Постановка проблеми

Формування нової моделі державноцерковних відносину у $\mathrm{GC}$ повинно враховувати кількість послідовників Церкви, іiі місце у формуванні історичної культурної та духовної спадщини європейських націй, їх ідентичності. При цьому Церква вважає за необхідне нагадати державі на необхідності дотримання своєї дистанції від проникнення в церковні справи. Протягом багатьох років у $\mathbb{E C}$ були вироблені дієві механізми взаємодії держави та Церкви, які можуть бути перенесені на вітчизняні терени з урахуванням національної специфіки, що актуалізує тему цієї статті. Стан дослідження. Проблеми правового статусу Церкви, вироблення оптимального механізму її взаємодії з державою та вирішення міжконфесійних конфліктів піднімаються вже десятки років. Із зазначених питань є суттєві наукові доробки О. Бикова, Д. Вовка, В. Сленського, С. Здіорука та інших науковців. Проте проблема визначення правового аспекту державно-церковних відносин та подолання міжконфесійних конфліктів на підставі зарубіжного досвіду все частіше стає питанням юридичної науки та потребує додаткового комплексного узагальнення. Метою статті $є$ визначення вихідних засад правового регулювання державно-церковних відносин та вирішення міжконфесійних конфліктів у $\mathbf{E C}$ й Україні та окреслення шляхів їх уніфікації. 


\section{Виклад основних положень}

Ідеологічна доктрина християнства відображає їі погляди на сучасні проблеми світу і суспільства і пропонує національним державам та політичному керівництву $\mathrm{EC}$ свою концепцію церковно-державних відносин. Ïї особливістю в нових умовах $є$ те, що церква знаходиться на провідних ролях у політичному просторі не тільки в Европі, але й у світовій спільноті. Держава в цій концепції не може обійтися без Церкви, оскільки держави потребують участі у вирішенні не тільки соціальних проблем, а й усього спектру державної політики. Цікаво, що Ватикан гарантує свою лояльність політичному керівництву $\mathrm{EC}$, у той же час обмежуючи можливість світської влади впливати на справи Церкви [1].

Останнє може підтверджуватися, зокрема, регулюванням фінансово-економічних відносин між Ватиканом та деякими Урядами європейських країн. Ватикан обгрунтував для держави нову доктринальну концепцію - право на існування єдиної європейської ідеологічної концепції мислення. Церква запропонувала інше розуміння вищих цінностей людини і її прав, які потрібні для здійснення високого покликання «служіння» Церкви самому GC та окремим національним Урядам.

У зв'язку з цим різниться і зміст, що вкладається в принцип відділення церкви від держави. Для більшості країн-членів СС таке відділення означає нейтралітет держави по відношенню до релігійних інститутів, що дозволяє і державі, і церкві функціонувати автономно в належних їх компетенції сферах. При цьому, відділення має на увазі співпрацю в тих сферах, де інтереси держави і церкви перетинаються. У багатьох випадках держава або прямо, або опосередковано фінансує церкву, направляючи кошти на утримання харитативних установ, військових капеланів, лікарень, інтернатів, а також будівництво і реставрацію сакральних будівель. Також важливим фактором зацікавленості держави у співпраці з релігійними організаціями $є$ сприяння релігійним інститутам у їхньому служінні інтересам держави. Державні та релігійні інститути часто йдуть найбільш легким шляхом, стимулюю- чи заборонні акції з боку законодавчої та виконавчої влади. Подібний метод вирішення проблеми зрозумілий, але стратегічно неефективний з точки зору збереження і розвитку власної духовно-культурної традиції [2]. Однак таке розуміння існування церкви і держави потребує переосмислення, що є об’єктивною вимогою часу та викликів сучасного періоду європейської інтеграції.

Політика співпраці держави і церкви набула нового тлумачення в країнах EC, які відчули на собі найбільший вплив негативних чинників від наслідків трансформаційних процесів, пов'язаних із інтеграцією $\mathrm{EC:}$ міграційні потоки, ослаблення економічної незалежності, проникнення ТНК, збільшення рівня безробіття на національних ринках [3].

Саме тому державно-церковні відносини потребують саме кооперації, а не лише співіснування чи взаємодії заснованій на системі певних загальних принципів чи установчих засад. «Вигода і для держави при вирішенні соціальних проблем, і для церкви, яка стає визнаним інститутом особливого роду в громадянському суспільстві полягає у тому, що досягається синергетичний ефект: установлення єдиної церкви та формування єдиної системи цінностей заснованих на релігійному вченні. У сучасній Європі очевидна тенденція до підвищення ролі кооперації в державноцерковних відносинах на основі принципу відділення і при відсутності державної релігії (церкви), що реалізує легітимну співпрацю держави і релігійних організацій. Демократичні принципи закладені в основі загальноприйнятих міжнародних положеннях, що стосуються релігійної свободи та сфери правового регулювання відносин держави i релігійних об'єднань у Свропі. Фундаментом європейських держав, при регулюванні відносин держави з релігійними об'єднаннями становить принцип, заснований на тому, що держава зобов'язана захищати громадян i суспільство від негативних наслідків діяльності деструктивних релігійних організацій» [4]. Тобто держава перетворюється на захисника Церкви та релігії від зовнішніх посягань, зокрема ісламського світу.

Така картина була характерною для Свропи епохи раннього середньовіччя, коли 


\section{Теорія, історія держави і права, конституційне право}

Церква захищала роздрібнені та досить слабкі національні держави від ісламської експансії. Церква потребує захисту через те, що сучасний рівень релігійних свобод майже нівелює значення проповідей та поширення місіонерської діяльності християнських проповідників. Держава не обмежує релігійні свободи, а тому існуе потреба у створенні нових прогресивних засобів захисту саме католицької церкви в межах EC. Це знову ж таки досягається за рахунок кооперації зусиль та узгодження позицій Церкви і держави. Ватикан пропагує релігійну рівність, але робить це в спосіб протиставлення цінності різних релігій, причому цінності християнства демонструються як найвищий рівень еволюції суспільної думки [5]. Церква визнала державу гарантом збереження духовних i культурних традицій європейської нації, у тому числі тих, що історично сформувалися під впливом церкви. Церква співпрацює 3 державою, сприяючи протидії псевдорелігійним структурам, які становлять небезпеку для особистості та суспільства. «Таким чином , у питанні правової інституціоналізації моделей державно-церковних відносин європейські держави опиняються в положенні, коли з одного боку, існує різноманіття і унікальність національних моделей, з іншого, існує стійка тенденція до їх уніфікації на базі деяких універсальних наднаціональних стандартів, враховуючи окремі специфіки історично сформованих в кожної країні форм відносин держави і Церкви. Европейські норми, які регулюють права людини і громадянина, поступово імплементували нову форму організації світської та церковної влади. Відбулося переосмислення теоретичних конструкцій дослідників, що призвело до кризи кожної окремо взятої національної моделі державно-церковних відносин [6]. Це дає змогу говорити про існування або об'єктивне відтворення та майбутню формацію нової прогресивної пан'європейської моделі державно-церковних відносин. За такої моделі держава, займаючи панівне становище з точки зору їі монополії на нормотворчість, створює передумови для існування релігійної єдності в соціумі як запоруки стабільності суспільного розвитку.
Перекладаючи такі тенденції на вітчизняну українську дійсність, слід перш за все навести приклад політичної волі керівництва країни для установлення релігійної єдності шляхом започаткування процесу отримання томосу єдиною помісною православною церквою України. В умовах євроінтеграції нашої держави такий процес є однозначним здобутком на шляху до подальшої демократизації суспільних процесів. Оскільки нами неодноразово доводилося в рамках цього дослідження, що релігія та Церква формують систему національних цінностей, впливають на аксіологічний вимір правопорядку та поняття законності, створюють умови для формування індивідуальної та суспільної свідомості (у тому числі правосвідомості) - тому контроль 3 боку будь-якого світського утворення за діяльністю церкви є неприйнятним [7].

Для України такий контроль здійснювався не лише супроти цивілізаційних орієнтирів української нації, але і ворожими державними інститутами РФ, яка контролює діяльність Руської православної церкви, яка, у свою чергу, вважає Україну власною єпархією. Українська православна церква, маючи два підпорядкування: Москва та Київ - спричиняють суттєвий етнорелігійний конфлікт, що є джерелом соціальної напруги для всього ЕС. Тому для подальшої інтеграції України в Союз необхідно вирішити питання релігійної єдності. Звертаючи увагу на традиційний зв'язок частини українських вірян 3 греко-католицькою та римо-католицькими церквами, зазначимо на проявах неабиякої толерантності та релігійної терпимості 3 боку цих церков до Української православної церкви Київського патріархату і навпаки.

Це засвідчує на тому, що українське суспільство, яке задовольняє духовні потреби через духовенство Української православної церкви Київського патріархату, сприймає толерантність як одну з найважливіших демократичних цінностей. Нами зазначалося, що саме толерантність є тим ідентифікатором приналежності до європейського соціуму, а отже, підтримка українського політичного керівництва Української православної церкви Київського патріархату засвідчує на 
прийнятті єдиного шляху розвитку держави - у межах EC [8].

Можна констатувати той факт, що для України релігійна єдність відіграє більшу роль ніж для СС у цілому, оскільки України не $є$ монорелігійною державою, рівень міжконфесійного протистояння, у якій штучно підтримується. Тому і модель державноцерковних відносин повинна зазнати суттєвих змін і трансформації, значно більшої та структурно глибшої, ніж у країнах EC. Aле той факт, що ані політичні, ані духовні лідери EC не критикували, а навпаки підтримували ініціативу політичного керівництва щодо отримання томосу для проголошення і утвердження єдиної помісної української православної церкви, свідчить про нову історичну добу у відносинах держави та церкви. Приклад України засвідчує, що церква реально, а не номінально чи декларативно підтримує та активно пропагує національну, культурну, ментальну єдність. Церква здатна бути гнучкою в питаннях максимізації чи мінімізації впливу духовенства на суспільні процеси, але позиція церкви спрямовується на підтримку тези щодо людського життя як найвищої цінності, а тому завжди підтримуватиме гуманістично налаштовані політичні режими [9].

Натомість держава здатна відійти від тези невтручання у внутрішньоцерковні справи, так само як і церква готова відійти від тези про обмеження свого впливу в публічно-політичній сфері. Хоча останне навряд чи можливе через активну участь у політичних процесах у низці європейських країн, політичних партій, заснованих на базі релігійних осередеків. Досягається певний компроміс, який скоріше схожий навіть на кооперацію, і саме така кооперація формує нову модель державно-церковних відносин, де зусилля обох сторін однаково спрямовані на досягнення стану загального блага або загальної безпеки, щоправда способи реалізації такого завдання у держави i церкви ріні. Держава діє через встановлення диспозитивів для моделей суспільної поведінки, натомість релігія і церква встановлюють низку моральних імперативів діяльності конкретного індивідуума та організації суспільних процесів.

\section{Висновок}

За результатами проведеного дослідження правового регулювання державноцерковних відносин та впливу релігійного фактору в Україні на процеси європейської інтеграції було зроблено наступні висновки, які розкривають глибинні проблеми державно-церковних відносин та доводять об'єктивність отримання українською православною церквою незалежності у формі автокефалії, та участі у цих процесах політичної влади країни, необхідності конституційно-правового закріплення цих процесів та формування нормативно-правового забезпечення у сфері релігійних відносин 3 метою мінімізації ризиків міжконфесійних конфліктів [10].

1. Встановлено, що в сучасних умовах в Україні міжконфесійні відносини є джерелом соціальної напруги та ризиків, але разом з тим і публічно-політичним потенціалом для активізації діалогу між політичним керівництвом України та EC. Інтеграція держави не можлива без інтеграції системи цивілізаційних цінностей української нації в єдиний культурологічний європейський простір. Навіть за умови позбавлення такого простору чітко вираженого центру, його релігійна аксіологічна домінанта зберігається, що означає можливість досягнення певного рівня порозуміння між церквами EC та України [11]. Конституційно-правовий вимір цих процесів потребує розширення ролі держави в регулюванні релігійних та міжконфесійних відносин. При чому регу^ювання останніх повинно відбуватися в спосіб, який у найбільшій мірі відповідає потребам досягнення безпекових критеріїв інтеграції в EC. Міжетнічні та міжконфесійні конфлікти в Україні повинні стати об'єктом державного впливу на етапі загостренні відповідних ризиків, що можливо забезпечити за рахунок розширення системи конституційних прав та свобод людини і громадянина в релігійній та духовній сферах. У цьому контексті Основний закон розглядається як декларація готовності та спроможності держави забезпечити високий рівень якості організаційно-правового забезпечення євроінтеграційних процесів, а закріплення 


\section{Теорія, історія держави і права, конституційне право}

в Конституції України норм щодо регулювання правового статусу учасників міжконфесійних відносин та правового режиму їх реалізації дасть змогу суттєво підвищити оперативність уніфікації вітчизняного законодавства із правом EC [12].

2. Встановлено, що сучасна система міжнародного права та права EC демонструє неухильне дотримання принципу свободи совісті та віросповідання, а також поступову деталізацію цього принципу і навіть створення прецедентів щодо розширення релігійних свобод особи. Однак еволюція права EC демонструє наявність двох тенденцій: розширення свободи совісті та свободи діяльності релігійних організацій; налагодження співпраці з релігійними організаціями та сприяння розвиткові міжконфесійного діалогу [13]. У цьому контексті цілком логічним вбачається, те що європейські акти у сфері регулювання релігійних свобод є похідними від міжнародно-правових актів глобального характеру, але при цьому містять і низку особливостей продиктованих специфікою культурного, ментального та релігійного середовища історичного розвитку Європи та прямим впливом Ватикану на процеси їх розробки і затвердження. Через активний вплив Ватикану право EC набагато ширше розкриває та деталізує різноманітні аспекти релігійного буття особи, у тому числі засобами прецедентного права та судової нормотворчості, ніж право інших країн. Важливість такого висновку для України демонструє наявність спроможності православної церкви формувати не лише систему суспільної свідомості з імплементацію в неї євроінтеграційних детермінантів, але і аспектів розвитку конституційно-правового забезпечення прав та свобод людини і громадянина [14].

\section{Мiтература}

1. Биков О.М. Правове регулювання відносин у сфері реалізації права на свободу віросповідання в Україні. Монографія / О.М. Биков. К.: Інститут законодавства Верховної Ради України, 2011. 344 с.

2. Віллем Ж.-П. Европа та релігії: ставки XXI ст. [пер. з фр.] / Ж.-П. Віллем. - К.: ДУХ і ЛITEPA, 2006. $331 \mathrm{c}$.
3. Вовк Д. О. Право і релігія: загальнотеоретичні проблеми співвідношення: монографія / Д. О. Вовк. Харків: Право, 2009. $224 \mathrm{c}$.

4. Сленський В. Велике повернення: релігія у глобальній політиці та міжнародних відносинах кінця XX початку XXI століття / В. Еленський. - Аьвів: Видавництво УКУ, 2013. 504 с.

5. Єленський В. Релігійно-суспільні зміни в посткомуністичній Европі / В. Еленський // Аюдина і світ. 1999. № 7. С. 30-36.

6. Еленський В. Релігія після комунізму. Релігійно-соціальні зміни в процесі трансформації центрально- і східноєвропейських суспільств: фокус на Україні / В. Сленський. - К.: НПУ ім. М.П. Драгоманова, 2002. 419 c.

7. Ермакова, Г. С. Конституційноправове забезпечення міжконфесійних відносин в Україні: питання теорії та практики. / Ганна Станіславівна Ермакова // Дисертація на здобуття наукового ступеня доктора юридичних наук. К.: Інститут законодавства Верховної Ради України, 2019. 344 c.

8. Жосул Е. В. Религиозный фактор в процессах политической интеграции и дезинтеграции в Европе : дис. к. полит. н.; специальность 23.00.02 / Е. В. Жосул. М.: Моск. гос. ун-т им. М.В. Аомоносова, 2008. 183 с.

9. Здіорук С.I. Суспільно-релігійні відносини: виклики Україні XXI століття: монографія / С. І. Здіорук. К.: Знання України, 2005. 552 c.

10. Ковбан А. В. Конституційно-правова регламентація права людини на свободу світогляду та віросповідання в Україні: дис. к.ю.н. ; спеціальність 12.00.02 - конституційне право; муніципальне право /А. В. Ковбан. Одеса: ОНУ ім. I.I. Мечникова, 2010. 237 с.

11. Релігійна свобода: Свобода релігії i міжрелігійний діалог: глобальні виміри i локальні вияви / Науковий щорічник УВК.№ 16.2011 .309 с.

12. Релігійний чинник у процесах націєта державотворення: досвід сучасної України : монографія /авт. кол : В. Войналович (керівник), В. Сленський, М. Кирюшко,Н. Кочан, Н. Рубльова. К. : Ін-т політ. і етнонац. дослідж. ім. І. Ф. Кураса НАН України, 2012. 272 c. 


\section{АНОТАЦІЯ}

y статті розглянуто Европейсъкі моделі церковно-державних відносин. Визначено, що політика співпрачуі держави $і$ иеркви набула нового змісту останнім часом у краӥнах $E C$ через вплив негативних чинників від наслідків трансформаиійних процесів пов'язаних із інтеграчією. Саме тому державно-церковні відносини потребують саме кооперациі, а не лише співіснування чи взаємодї заснованій на системі певних загальних приниипів чи установчих засад. Демократичні приниипи закладені в основі загальноприйнятих міжнародних положень, що стосуються релігійної свободи та сфери правового регулювання відносин держави $i$ релігійних об’єднань в Европі. Свропейські норми, які регулюють права людини $i$ громадянина, поступово імплементували нову борму організаиї світської та иерковної влади. Це дає змогу говорити про існування або об'єктивне відтворення та майбутню формаиію нової прогресивної пан-європейсъкої моделі державно-иерковних відносин, яку із врахуванням національних особливостей доцільно запозичити в Україні для подальшої демократизаиї суспільних процесів.

Висвітлено наявність міжконфесійних конфліктів в Украӥні, що потребують вирішення за допомогою богословсъких $i$ Европейсъких правових механізмів.

Ключові слова: держава, Церква, державно-церковна модель, державно-церковні відносини, релігія, суспільство, конфесія.

13. Сьомін С. Державно-церковні відносини: світовий досвід і Україна (історико-політичний аналіз): Монографія / С. Сьомін, Ю. Кальниш, В. Петрик, В. Остроухов / [ред. І. Тимошенко]. К.: Вид-во Европ. унту, 2002. $136 \mathrm{c}$.

14. Ярмол А. В. Свобода віросповідання людини: юридичне забезпечення в Україні (загальнотеоретичне дослідження): дис. к. ю. н. ; спеціальність 12.00.01 / Л. В. Ярмол. А.: Аьвівський національний ун-т ім. Івана Франка, 2003. 238 с.
Hanna S. Yermakova,

Private Joint-Stock Company "Higher education institution 'Interregional Academy of Personnel

Management", https://orcid.org/0000-0002-2665-8949

Volodymyr I. Polevyy

Berdyansk University of Management and

Business

https://orcid.org/0000-0001-9212-2475

EUROPEAN LEGAL SYSTEM IN THE

DEVELOPMENT OF STATE-CHURCH

RELATIONS IN UKRAINE

The most models of church-state relations and try to adapt them to characterize the Ukrainian. It has been determined that the policy of cooperation between the State and the Church has acquired new content in recent years in the EU countries due to the influence of negative factors from the consequences of transformational processes related to integration. That is why State-Church relations require cooperation, not just coexistence or interaction based on a system of certain general conditions. Democratic principles are based on generally accepted international provisions relating to religious freedom and the legal regulation of relations between the State and religious associations in Europe. European norms governing human and civil rights gradually introduced a new form of organization of secular and ecclesiastical power. This makes it possible to speak of the existence or objective reproduction and future formation of a new progressive pan-European model of State-Church relations, which, in view of ethnic peculiarities, it is advisable to borrow in Ukraine for the further democratization of social processes.

The article indicates of the presence of the inter-denominational conflicts that require resolution with the help of theological and European legal mechanisms.

Keywords: State, Church, church-state model, church-state relations, religion and society, confession. 